Article

\title{
The Effects of Corporate Social Responsibility (CSR) Fit and CSR Consistency on Company Evaluation: The Role of CSR Support
}

\author{
Dongho Yoo and Jieun Lee * \\ School of Business Administration, Chung-Ang University, 84, Heukseok-ro, Dongjak-gu, Seoul 06974, Korea; \\ toocalm@cau.ac.kr \\ * Correspondence: jlee114@cau.ac.kr; Tel.: +82-10-8830-3884
}

Received: 20 July 2018; Accepted: 17 August 2018; Published: 20 August 2018

\begin{abstract}
With growing interest in corporate social responsibility (CSR), companies are utilizing it as a public relation (PR) tool for corporate image change. Previous research suggests that the fit between a company and CSR activity is a key determinant of CSR success. They show that, the higher the CSR fit, the more positive the consumers' evaluations are. However, although many companies undertake various CSR activities, there is no research examining the effect of consistency among various CSR activities. In addition, there is a lack of explanation for cases where consumers positively evaluate low CSR fit. In this study, we examine CSR fit, consistency among various CSR activities (CSR consistency), and the degree of consumer support for CSR activities (CSR support). Our multiple regressions show that higher the CSR support, the more positive is the consumer's evaluation of the company. In addition, when CSR support is high, the effect of CSR fit and CSR consistency on company evaluations is insignificant. However, when consumer support for CSR activities is low, company evaluations are positive only when both CSR fit and CSR consistency are high. In addition, the influence of three variables on company evaluation is mediated by CSR motives. Finally, we discuss the implications of this study.
\end{abstract}

Keywords: CSR; CSR fit; CSR consistency; CSR support; perceived CSR motive; company evaluation

\section{Introduction}

As corporate sustainability, which indicates company activities demonstrating the inclusion of environmental and social concerns in business operations and in interactions with stakeholders [1], is becoming increasingly important for society [2] and corporate social responsibility (CSR) is recognized as indispensable for corporate sustainability, interests in CSR activities is explosively growing. Companies are now utilizing CSR as a public relation (PR) tool to change their corporate image, in addition to focusing on their responsibility towards society [3]. Thus, CSR activities can be an important strategy for attracting consumer attention in today's competitive market environment [4].

However, despite corporate commitment to CSR, there is no clear empirical evidence on the impact of CSR activities on corporate performance. For example, research shows that the relationship between CSR activities and corporate performance is positive [5]. However, some studies suggest that CSR has a negative effect on corporate performance [6,7]. Studies on consumer perception of CSR activities also reveal inconsistent results. Some studies show that CSR activities enhance consumer satisfaction [4,8], while others emphasize that CSR activities raise persuasion knowledge or CSR hypocrisy among consumers, resulting in negative evaluation of companies $[9,10]$. Prior studies on CSR activities do not provide a clear direction in practice; therefore, there is a need to provide practical guidance to companies for effective CSR activities. 
Previous research suggests that the fit between company and CSR activities is a key variable for CSR success and argues that the higher the CSR fit, the more positive the consumers' evaluations [11]. This is because a higher CSR fit shows a stronger association between the company and CSR activities, and the positive aspects of the activities are more easily transferred to the company. Meanwhile, although many companies are engaging in diverse CSR activities, and some activities have high fit with the company, others do not. For example, Coca-Cola engages in CSR activities, such as "climate protection", "human and workplace rights", "packaging and recycling", "water stewardship", and "women's economic empowerment". However, some studies have examined the effect of consistency of CSR activities. In addition, why consumers positively evaluate CSR activities despite a low fit between CSR activities and the company still lacks explanation. For example, consumer response to Audi's sponsorship of the Salzburg Festival, one of the world's most famous music festivals, was positive, despite a low CSR fit with the company [12].

This study suggests CSR consistency, which indicates similarity among various CSR activities that the company executes, and CSR support, the degree of consumer's support for the CSR domain, as the key variables. According to previous studies, if CSR consistency is high, the presented information among CSR activities is easily integrated and positively evaluated; however, a lack of consistency due to contrast among suggested information leads to more thought and elaborate thinking by consumers, and finally lead to a negative response [13-17]. However, CSR literature has not sufficiently investigated the effects of CSR consistency. Furthermore, previous studies examined the role of CSR support as an important variable in a consumer's evaluation, and argue that CSR activities in areas that consumers consider to be important are making consumers share their interests with company and this leads to a positive company evaluations and purchase intentions [18]. Thus, CSR support is a very important variable in consumers' judgments of CSR activities. However, most previous studies $[18,19]$ regard CSR support as a moderating variable that controls the role of other independent variables in explaining CSR performance. In this study, we focused on CSR support as an independent variable that plays an important and direct role in the evaluation of CSR companies. Moreover, we investigated the interaction effects between CSR fit and CSR consistency on consumer responses, as well as the main effect of CSR support.

The purpose of this study is to investigate the effects of consumers' support for CSR activities, CSR fit, and CSR consistency on company evaluations by using diverse CSR activities. In addition, we examine the mediating role of perceived CSR motives. The findings of this study are expected to extend CSR literature and provide practical implications for the development of successful CSR strategies.

This study proceeds as follows. In the following section, we present the literature review, development of hypotheses, and research method. Then, the results of hypotheses testing are discussed. Finally, this study discusses implications and conclusions including limitations and suggestions for future research.

\subsection{CSR and CSR Information}

CSR is defined as a company's commitment to eliminating or minimizing any harmful effects and maximizing its sustainable beneficial impact on society [20]. Companies are implementing various forms of CSR activities, such as charitable donations, the use of green materials, and diversity initiatives [18]. Likewise, researchers and practitioners have become increasingly interested in the positive impact of CSR [21]. Previous researches suggest that CSR is positively linked to consumers' affective and behavioral responses [18,22-26], market value of the company [4,27], and financial performance $[4,7,27,28]$.

More recently, researchers are paying increasing attention to the impact of CSR information as non-financial information. They showed that the inclusion of CSR information as non-financial information (NFI) in sustainability reports produces positive effects on the stakeholders' responses and the company's market value [29,30]. In particular, Venturelli et al. [30] developed NFI scores 
to analyze the company's compliance level in the areas of business model, sustainability policies, sustainability risks, KPIs (key performance indicators), and diversity. They found that CSR information in sustainability reports has positive impact on NFI scores, especially when companies already involved in CSR programs, such as voluntary and assured sustainability reports.

\subsection{CSR Fit}

Fit is defined as a "match between two or more factors" [31] (p. 537), such as a product, brand image, position, or target market [32]. Therefore, CSR fit refers to the perceived relevancy between characteristics of a company and its CSR activities [11].

Previous studies on CSR fit have suggested that it affects consumer responses in several ways. First, when consumers think about the relationship between the firm and its associated things, the number of thoughts on the two objects varies by the degree of fit between them. Consumers elaborate their thoughts on the company more, if they recognize that their expectations about the company and the information presented are inconsistent [33-35]. Second, the type of consumer thoughts is affected by the degree of fit. Low fit causes consumers to have adverse thoughts and low fit itself is perceived negatively [33]. In particular, low fit leads consumers to have a negative perception of CSR motivation [36,37]. In other words, low-fit CSR activities increase consumers' cognitive elaboration and adversely affect their perceptions of corporate motivation [3]. In turn, it makes consumers doubt the sincerity of CSR activities. Finally, fit influences a consumer's evaluation of the company and its CSR activities. Consumers tend to reinforce self-esteem or self-identity by purchasing products from companies that are engaging in high-fit CSR activities, as high-fit CSR activities strengthen the associations between the company and CSR activities, which in turn, positively affects the self-esteem and identity of consumers. Therefore, higher the CSR fit, the more favorable the consumers' evaluation of the company.

Previous studies have revealed the effects of CSR fit on consumers. Speed and Thompson [38] found that higher the CSR fit, the greater the consumers' interest and favorability toward the company, and thus, the consumer is more willing to use the company's products. Becker-Olsen, Cudmore, and Hill [11] argued that brand characteristic becomes more prominent when the CSR fit is high. In addition, they suggested that consumer recollection varies with the degree of CSR fit, because a low fit tends to generate a greater number of thoughts than high fit.

\subsection{CSR Consistency}

Consistency refers to the degree to which two or more objects are similar in form or structure [39] and it affects the attitudes of consumers and the success of marketing strategies [40,41]. In this study, CSR consistency is defined as the similarity among various CSR activities that the company implements in a regular and systematic manner [42].

Previous research suggests that consistency has a positive effect on consumer attitude. This is because consumers tend to integrate information when exposed to different types of information, and inconsistent information generates negative thinking by elaborating consumers' thoughts [13-17]. Maheswaran and Chaiken [14] found that, when consumers evaluate products, their thoughts become more elaborate when they are presented with inconsistent information than when information is consistent. In addition, inconsistent information causes conflicts between different evaluation factors, creating an aversion to existing information $[43,44]$. On the other hand, if consumers recognize objects, they reduce their efforts to search for additional information [45]. Previous research argues that the integrated image that is formed by consistency has a positive effect on consumers' evaluation of new products [23,46]. In other words, consistent information leads to positive responses by reducing consumers' efforts to search for additional information, while inconsistent information elaborates consumers' thoughts and causes negative reactions to previous information.

Marketing literature argues that consistency in marketing activities is an important factor for the success of marketing strategies [40,41]. For example, Swait and Erdem [41] investigated the impact 
of consistency in sales promotion in retail shops on consumer product evaluations and found that consistency in the sales promotion mix positively influenced the utility perceptions of consumers. However, when consumers perceive low consistency among activities, it decreases the perceived utility. The importance of consistency in the sales promotion mix is applicable to corporate CSR activities. Consistency increases the credibility of CSR activities and induces consumers to expect that companies will continue to pursue similar types of CSR activities in the future. However, inconsistent CSR activities cause consumers to perceive such activities as temporary, unplanned, and random [42]. In addition, CSR activities with low consistency negatively affect the motivation of the company. That is, consumers may consider CSR activities as window-dressing or gimmicks.

Therefore, we expect that consumer evaluations will be more positive when CSR activities are consistent than when they are inconsistent. This is because high consistency of information allows for it to easily integrate into a whole image and reduces the efforts of consumers in searching for additional information.

\subsection{CSR Support}

CSR support is defined as the degree of consumer advocacy of corporate CSR activities, and a high level of CSR support suggests that consumers are highly aware of the congruence between themselves and CSR activities [18]. How does CSR support affect consumers' corporate evaluations?

In general, CSR support is known to depend on consumers' familiarity with CSR activities [47], the importance of issues to the self [48], and personal relevance [49]. First, the higher the consumers' familiarity with CSR activities, higher the CSR support. This is because consumers process information through the central route when familiarity is high; however, they process it through the peripheral route when the familiarity is low. Similarly, Drumwright [47] suggested that if consumers have a high level of familiarity with CSR activities, the likelihood of success in CSR activities increases. Second, if the domain of CSR activity is considered to be significant for the individual, the level of CSR support increases. CSR activities that are related to important issues for individuals reinforce the relationship between the self and the company, leading to support for CSR activities. Finally, if the personal relevance of CSR activity is high, the consumer's level of support also increases. According to identity theory, people have different identities in different relationships [50], and some identities reflect better than others. A more relevant and prominent identity with an individual has more significance to the self, thus, making it more likely that an individual will perform identity-related behaviors [50-53]. People who perform identity-related behaviors give positive self-evaluation and have higher perceived self-esteem [54]. Therefore, people with strong identities try to perform their identity-related behaviors successfully [55]. This explains why CSR support is caused by the consumers' perceived self-identity and why high CSR support is associated with a high degree of personal relevance and identity. Meanwhile, signaling theory presents that company information is not equally available to all consumers at the same time, and information asymmetry occurs [56,57]. These information asymmetries can result in consumers' low valuations of company. In order to overcome this, companies convey some meaningful information, such as brand name and CSR activities [56,58] about the company (that is, its 'signals') to consumers. Thus, CSR information serves as a signal to consumers and reduces the information asymmetry. Previous research suggested that the more positive the signal, the more favorable the consumer responses [56]. Because high CSR support means that the signal is positively perceived by consumers, it leads to a positive corporate evaluations. Indeed, previous studies demonstrated the positive impact of CSR support on consumer response.

However, despite of the significant role of CSR support on the consumer responses, most previous studies $[18,19]$ treat CSR support as moderating variable that controls other independent variables and no direct influences on consumer evaluations. For example, Sen and Bhattacharya [18] found that CSR support moderates the interaction effects of new product quality information and CSR information on company evaluation and purchase intention. Pérez and Rodríguez del Bosque [19] found that CSR support moderates the formation process of consumers' perceptions of CSR activity. In contrast, 
we focused on CSR support as independent variable that plays an important and direct role in the evaluation of CSR companies. High CSR support leads to more positive consumer attitudes toward CSR activities and makes consumers perceive the high congruence between their personality and that of the company. The congruence between consumers and the company has a positive impact on company evaluations by consumers [18]. Therefore, higher the CSR support, the more positive are consumers' evaluations. Hence, we propose the following hypothesis.

Hypothesis 1 (H1). CSR support has a positive impact on consumers' company evaluations.

We also expect that CSR support, CSR fit, and CSR consistency will have interaction effects on company evaluations. First, when CSR support is high, CSR fit and CSR consistency are expected to have no significant effect on company evaluations. Consumers tend to judge the value of information by comparing it with internal references $[59,60]$. If the value of the information is perceived to be equal to or better than the internal references, the consumer does not change attitude or express high satisfaction. However, if the value of the information does not meet their internal references, consumers try to search for additional information [61,62]. High CSR support means that consumers evaluate that CSR activities are valuable in the light of their internal references. Thus, consumers are less motivated to search for additional information, and CSR fit and CSR consistency will have no impact on company evaluations.

On the other hand, if CSR support is low, consumers tend to seek additional information because CSR activity does not meet consumers' internal references [59,60]. Therefore, we expect that consumers' evaluations will vary depending on the CSR fit and CSR consistency. Specifically, when both CSR fit and CSR consistency are high, consumers' evaluations will be more positive. This is because when both CSR fit and CSR consistency are high, the presented information can easily be combined or assimilated to existing expectations. However, when either CSR fit or CSR consistency is low, consumers have difficulty in integrating multiple pieces of information into the overall image, thus consumers' thoughts will be elaborated [14,33-35]. This results in consumers' negative reactions to the company. In addition, low CSR fit and low CSR consistency cause consumers to have negative perceptions about corporate CSR motivation, which negatively impact their evaluations. Thus, Hypothesis 2 is as follows:

Hypothesis 2 (H2). When CSR support is high, CSR fit and CSR consistency have no significant influence on the evaluation of consumers. However, when CSR support is low, consumers' company evaluations will be significantly positive when both CSR fit and CSR consistency are high compared to the other conditions.

\subsection{Perceived CSR Motives}

Perceived CSR motives are defined as the consumers' perceptions of the motivation behind the corporate CSR activities [63]. In other words, perceived CSR motives refer to how much authenticity or hypocrisy consumers believe about corporate CSR activities. Previous research has argued that perceived CSR motives have a positive impact on consumers' evaluations about the company $[10,63]$. The impact of CSR is enhanced when a company's motives for CSR are perceived as sincere [10]. Forehand and Grier [33] found that stronger perceptions of public-serving motives result in positive responses of consumers about the company. Alhouti, Johnson, and Holloway [64] found that when consumers perceive CSR motives as public-serving, they feel authenticity in CSR, which leads to positive purchase intention and loyalty to the company. They found that when consumers perceived CSR motives as self-serving, CSR negatively influences perceptions of authenticity, purchase intention, and loyalty to the company. Park, Lee, and Kim [65] expressed perceived CSR motives as "social benevolence trust", and showed that perceived CSR motives positively affect corporate reputation. He and Lai [66] suggested that corporate ethical responsibility, when comparing to corporate legal responsibility, is understood as being honest in its relationship with its consumers. 
In addition, previous research has revealed that perceived CSR motives are more positive when the consumers' involvement in CSR activities is high [67], such as in situations where consumer support is high, when CSR fit is high [26,64], and when CSR activities are sustained [26]. Therefore, we expect that perceived CSR motives will mediate the effects of CSR support, CSR fit, and CSR consistency on company evaluations. Given this discussion, Hypothesis 3 is as follows:

Hypothesis 3 (H3). The effects of CSR support, CSR fit, and CSR consistency on company evaluations are mediated by perceived CSR motives.

\section{Materials and Methods}

\subsection{Data Collection and Sample}

The aim of this study is to investigate the effects of CSR support, CSR fit, and CSR consistency on company evaluations by adopting diverse CSR activities. The framework for our study is presented in Figure 1. Participants were Americans recruited from Amazon Mechanical Turk (MTurk). MTurk provides a practical way to hire a large number of subjects for online survey. Our survey was conducted between 1 February 2018 and 8 February 2018. Previous research shows that workers on MTurk are more demographically diverse than the traditional college subject pools [68,69].

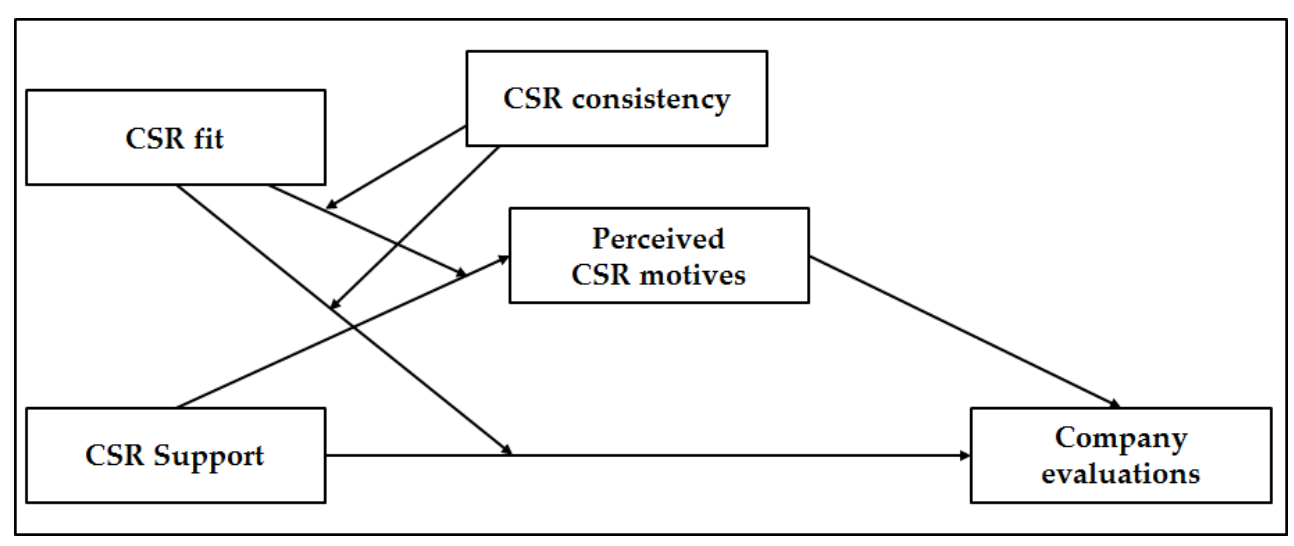

Figure 1. Conceptual model.

One hundred and seventy-seven people from Amazon MTurk participated in the study in exchange for monetary compensation, and they were assigned randomly to one of the four conditions based on two variables: CSR fit and CSR consistency. The sample size of each condition was 42-46. Of these, 48.6 percent $(n=86)$ were men, and their average age was 39.8 years $(\mathrm{SD}=11.37)$; the age range was 21-71 (Table 1).

Table 1. Characteristics of Sample.

\begin{tabular}{lccc}
\hline & Characteristics & N & \% \\
\hline \multirow{2}{*}{ Gender } & Male & 86 & 48.6 \\
& Female & 91 & 51.4 \\
\hline \multirow{4}{*}{ Age } & $20-29$ & 34 & 19.2 \\
& $30-39$ & 68 & 38.4 \\
& $40-49$ & 38 & 21.5 \\
& $50-59$ & 23 & 13.0 \\
& $\geq 60$ & 14 & 7.9 \\
\hline
\end{tabular}




\subsection{Development of Stimuli Materials}

We selected "automobiles" as the product category and Volvo was chosen as the company conducting CSR activities. The automobile market is a typical industry where companies are engaged in various CSR activities, but consumers may perceive the motivation of the company negatively. Indeed, many car manufacturers implement eco-friendly CSR activities, but consumers sometimes feel hypocrisy, such as "greenwashing" on these activities [70,71]. Therefore, a survey of consumers' perceptions of CSR motives based on the automobile market will provide further implications for companies in the market that are experiencing or are likely to experience the challenges that are associated with greenwashing. Experimental stimuli were produced in four different formats based on the type of CSR fit and CSR consistency (see Appendix A). For example, "supporting science and engineering", "children's traffic safety programs", and "supply vehicles for the disabled" were selected as high-CSR fit and high-CSR consistency activities with Volvo. For low-CSR fit and low-CSR consistency activities, "eradicating pediatric cancer", "disaster relief", and "popularizing culture and arts" were created.

We conducted a pretest to verify that the stimuli were appropriate. Forty people from Amazon Mechanical Turk (MTurk) participated in the pretest in exchange for monetary compensation. Of these, 52.5 percent $(n=21)$ were men, with average age 32.2 years $(\mathrm{SD}=11.29)$. The results showed that subjects perceived higher fit in the condition of high-CSR fit $(\mathrm{M}=5.35)$ than in the condition of low-CSR fit $(\mathrm{M}=3.15 ; \mathrm{t}=5.58, p<0.001)$, and that they perceived higher consistency in the condition of high-CSR consistency $(M=5.35)$ than in the condition of low-CSR consistency $(M=2.90 ; t=6.36, p<0.001)$.

\subsection{Methods}

Each participant received a scenario and a questionnaire. The scenario included a newspaper article about Volvo planning a new CSR activity. For example, the participants were informed that Volvo was currently carrying out CSR activities that were related to "supporting science and engineering" and "children's traffic safety programs" with "plans to further expand the supply of vehicles for the disabled". The participants then responded to the items of brand familiarity, CSR motives, company evaluations, CSR support, and to the manipulation check items for CSR fit and CSR consistency. Finally, they answered questions related to demographics.

This study collects the data through a questionnaire survey, and tests reliability and validity of the measurement scale. Reliability of the measurement scale is assessed by Cronbach $\alpha$ and validity of the measurement scale is examined by the factor loading. A multiple linear regression analysis is carried out to examine whether company evaluations is significantly affected by CSR support, CSR fit, CSR consistency, and the interactions between three variables. The following regression equations were estimated:

Company evaluations $=\alpha+\beta 1$ (Brand familiarity) $+B 2($ CSR support $)+B 3($ CSR fit $)+\beta 4$ $($ CSR consistency $)+B 5($ CSR support $\times$ CSR fit $)+B 6($ CSR support $\times$ CSR consistency $)+B 7($ CSR fit $\times$ CSR consistency $)+B 8($ CSR support $\times$ CSR fit $\times$ CSR consistency $)+\varepsilon$

Spotlight analysis is performed to better understand the nature of the interaction effects. Lastly, mediation analysis using model 12 in PROCESS macro is conducted to test whether perceived motives mediate the relationship between the effects of CSR support, CSR fit, and CSR consistency on company evaluations.

\subsection{Measures}

Brand familiarity, included as a covariate, was measured using a single item ("I am familiar with the brand"). Perceived fit ("The fit between the company and the CSR activities is high") and perceived consistency ("The CSR activities are consistent") was measured while using a single item. CSR support was measured while using four items adopted from Arnett, German, and Hunt [55]. Perceived CSR motives was measured with four items that were adopted from Bolton and Mattila [21]. Company 
evaluations refers to the consumers' positive or negative reactions to the companies engaging in CSR activities, and it was measured with four items adopted from Yoon, Gürhan-Canli, and Schwarz [10].

The factor loadings of each item were higher than 0.7 , demonstrating convergent validity, and Cronbach's Alpha was higher than 0.8 , indicating a high degree of internal consistency (see Table 2).

Table 2. Results of factor and reliability analysis.

\begin{tabular}{|c|c|c|c|c|}
\hline Variables & Items & $\begin{array}{l}\text { Mean } \\
\text { (SD) }\end{array}$ & $\begin{array}{l}\text { Factor } \\
\text { Loading }\end{array}$ & $\begin{array}{l}\text { Cronbach's } \\
\text { Alpha }\end{array}$ \\
\hline \multirow{4}{*}{ CSR support } & [CSR activity name] is an important part of who I am. & \multirow{4}{*}{$\begin{array}{c}3.78 \\
(1.71)\end{array}$} & 0.782 & \multirow{4}{*}{0.842} \\
\hline & $\begin{array}{l}\text { [CSR activity name] is something about which I have } \\
\text { no clear feeling (reverse-coded). }\end{array}$ & & 0.742 & \\
\hline & $\begin{array}{c}\text { [CSR activity name] means more to me than just } \\
\text { having a degree. }\end{array}$ & & 0.786 & \\
\hline & $\begin{array}{l}\text { [CSR activity name] is something I rarely think about } \\
\text { (reverse-coded). }\end{array}$ & & 0.826 & \\
\hline \multirow{4}{*}{$\begin{array}{l}\text { Perceived } \\
\text { CSR motives }\end{array}$} & $\begin{array}{l}\text { Volvo participates in CSR because it genuinely cares } \\
\text { about the well-being of others. }\end{array}$ & \multirow{4}{*}{$\begin{array}{c}4.42 \\
(1.41)\end{array}$} & 0.845 & \multirow{4}{*}{0.887} \\
\hline & Volvo's commitment to CSR is genuine. & & 0.824 & \\
\hline & $\begin{array}{l}\text { Volvo is really just engaging in CSR to benefit itself } \\
\text { (reverse-coded). }\end{array}$ & & 0.857 & \\
\hline & $\begin{array}{l}\text { Volvo participates in CSR because it wants to sell more } \\
\text { products (reverse-coded). }\end{array}$ & & 0.801 & \\
\hline \multirow{4}{*}{$\begin{array}{l}\text { Company } \\
\text { evaluations }\end{array}$} & How good or bad is Volvo? & \multirow{4}{*}{$\begin{array}{c}5.14 \\
(1.58)\end{array}$} & 0.947 & \multirow{4}{*}{0.983} \\
\hline & How likeable is Volvo? & & 0.941 & \\
\hline & How positive or negative is Volvo? & & 0.951 & \\
\hline & How favorable is Volvo? & & 0.926 & \\
\hline
\end{tabular}

\section{Results}

\subsection{Manipulation Check}

The regression results on perceived fit revealed a main effect of CSR fit $(\beta=0.36, \mathrm{t}(168)=3.64$, $p<0.001)$. The higher the CSR fit, the higher the perceived fit of the participants. The influence of other variables was not significant (all, $p>0.1$ ). The regression results on perceived consistency also showed a main effect of CSR consistency $(\beta=0.34, \mathrm{t}(168)=3.20, p<0.01)$. The higher the CSR consistency, the higher was the perceived consistency of the participants. The influence of other variables was not significant (all, $p>0.1$ ). Therefore, the manipulations of CSR fit and CSR consistency were successful.

\subsection{Company Evaluation}

We regressed the company evaluation on brand familiarity, mean centered CSR support index, CSR fit, CSR consistency, and the interactions between three independent variables. The results revealed the significant positive effect of the CSR support index $(\beta=0.35, \mathrm{t}(168)=2.27, p<0.05)$ on company evaluation. Thus, H1 was supported.

It was also found that there were significant interaction effects between CSR fit, CSR consistency, and CSR support index $(\beta=-0.26, \mathrm{t}(168)=-1.99, p<0.05)$ on company evaluation (see Table 3$)$. 
Table 3. Results of regression analysis for company evaluation.

\begin{tabular}{cccc}
\hline Variables & $\boldsymbol{\beta}$ & $\mathbf{T}$ & $\boldsymbol{p}$ \\
\hline Brand familiarity & 0.12 & 1.70 & 0.091 \\
CSR fit (A) & 0.06 & 0.58 & 0.562 \\
CSR consistency (B) & 0.08 & 0.82 & 0.413 \\
CSR support index(C) & 0.35 & 2.27 & 0.024 \\
A $\times$ B & 0.09 & 0.71 & 0.478 \\
A $\times$ C & 0.09 & 0.61 & 0.542 \\
B $\times$ C & 0.13 & 0.92 & 0.357 \\
A $\times$ B $\times$ C & -0.26 & -1.99 & 0.048 \\
\hline
\end{tabular}

Further, we examined the effects of the CSR support index on participants' company evaluation at each level of the CSR fit and CSR consistency. First, the CSR support index was not significant in the high-CSR fit and high-CSR consistency condition $(\beta=0.05, \mathrm{t}(87)=0.45, p>0.1)$, whereas the CSR support index was positive and significant in the high-CSR fit and low-CSR consistency condition $(\beta=0.40, t(87)=3.96, p<0.001)$. However, when the CSR fit was low, the CSR support index had a positive and significant influence on company evaluation, both in the high-CSR consistency condition $(\beta=0.49, \mathrm{t}(80)=3.61, p<0.001)$ and in the low-CSR consistency condition $(\beta=0.33$, $\mathrm{t}(80)=2.08, p<0.05)$.

We also conducted a spotlight analysis [72] at one standard deviation above and below the mean of the support index $(M=3.78)$. The result showed that when CSR fit was high, participants of high-CSR support did not differ in company evaluations between the high-CSR consistency condition and low-CSR consistency condition $(\beta=0.01, \mathrm{t}(87)=0.02, p>0.1)$, whereas the participants of low-CSR support gave more positive company evaluations in the high-CSR consistency condition than in the low-CSR consistency condition $(\beta=1.17, \mathrm{t}(87)=3.21, p<0.001)$ (see Figure $2 \mathrm{a}$ ). The results also revealed that when CSR fit was low, participants of both high-CSR support $(\beta=0.48, t(80)=0.95$, $p>0.1)$ and low-CSR support $(\beta=-0.06, \mathrm{t}(80)=-0.13, p>0.1)$ were not significantly different in company evaluation by the level of CSR consistency (see Figure $2 b$ ). Thus, H2 was supported.

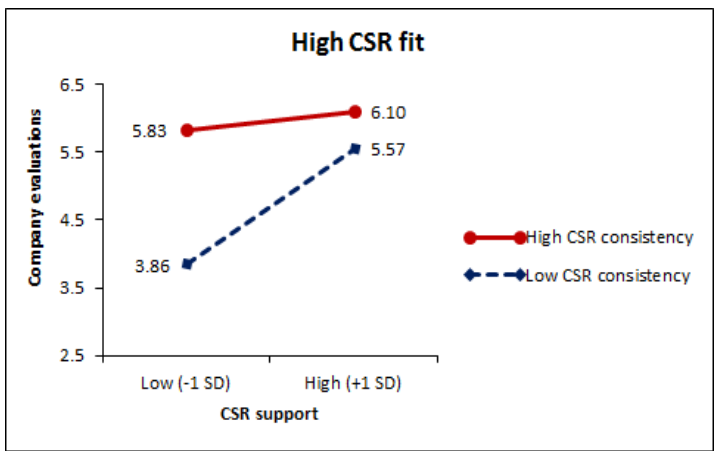

(a)

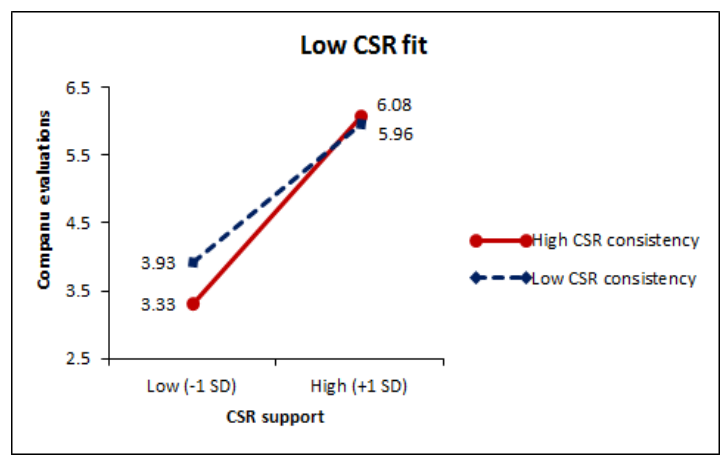

(b)

Figure 2. Interaction effects on company evaluations: (a) high-corporate social responsibility (CSR) fit condition; (b) low-CSR fit condition.

These results show that CSR support positively affects consumers' company evaluation, regardless of CSR fit and CSR consistency. However, when CSR support is low, consumers evaluated the company more positively in the high-CSR fit and high-CSR consistency condition when compared to the other conditions.

\subsection{Perceived CSR Motive}

To investigate the mechanism that underlies the results, we regressed the perceived CSR motives on brand familiarity as a covariate, mean centered CSR support index as independent variable, CSR fit, 
CSR consistency, and the interactions between three independent variables. The results revealed the positive effect of the CSR support index $(\beta=0.42, \mathrm{t}(168)=2.81, p<0.01)$ on the perceived CSR motive. That is, people with higher CSR support were found to have more positively perceived CSR motives. As predicted, the results also revealed a significant interaction effect of CSR fit, CSR consistency, and CSR support index $(\beta=-0.28, \mathrm{t}(168)=-2.14, p<0.05)$ (see Table 4$)$.

Table 4. Results of regression analysis for perceived CSR motive.

\begin{tabular}{clcc}
\hline Variables & $\boldsymbol{\beta}$ & $\mathbf{t}$ & $\boldsymbol{p}$ \\
\hline Brand familiarity & 0.02 & 0.23 & 0.819 \\
CSR fit (A) & 0.08 & 0.77 & 0.441 \\
CSR consistency (B) & -0.02 & -0.18 & 0.858 \\
CSR support index (C) & 0.42 & 2.81 & 0.006 \\
A $\times$ B & 0.16 & 1.29 & 0.200 \\
A $\times$ C & 0.10 & 0.74 & 0.463 \\
B $\times$ C & 0.04 & 0.25 & 0.804 \\
A $\times$ B $\times$ C & -0.28 & -2.14 & 0.034 \\
\hline
\end{tabular}

To further understand the interaction effects, the effects of the CSR support index on participants' CSR motive was examined at each level of CSR fit and CSR consistency. First, the CSR support index was not significant in the high-CSR fit and high-CSR consistency condition $(\beta=0.02, t(87)=0.20$, $p>0.1$ ), whereas the CSR support index was positive and significant in the high-CSR fit and low-CSR consistency condition $(\beta=0.47, \mathrm{t}(87)=5.15, p<0.001)$. However, when CSR fit was low, the CSR support index had a positive and significant influence on the perceived CSR motives, both in the high-CSR consistency condition $(\beta=0.39, \mathrm{t}(80)=3.22, p<0.01)$ and in the low-CSR consistency condition $(\beta=0.35, \mathrm{t}(80)=2.45, p<0.05)$.

We also conducted a spotlight analysis [72] at one standard deviation above and below the mean of the support index $(M=3.78)$. The result showed that, when CSR fit was high, participants of high-CSR support did not differ in perceived CSR motives of the high-CSR consistency condition and low-CSR consistency condition $(\beta=-0.46, \mathrm{t}(87)=-1.41, p>0.1)$, whereas the participants of low-CSR support perceived the company's CSR motives more positively in the high-CSR consistency condition than in the low-CSR consistency condition $(\beta=1.03, t(87)=3.16, p<0.01)$ (see Figure 3a). However, it was found that when CSR fit was low, participants of both high-CSR support $(\beta=0.01, t(80)=0.01$, $p>0.1)$ and low-CSR support $(\beta=-0.14, t(80)=-0.31, p>0.1)$ did not differ significantly in perceived CSR motives by the level of CSR consistency (see Figure $3 b$ ).

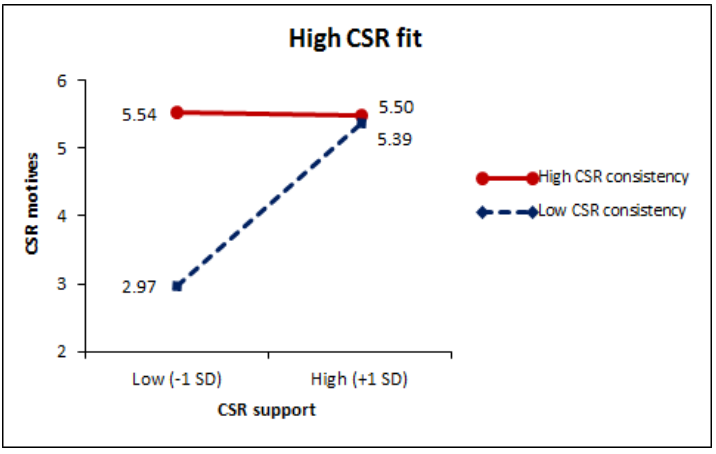

(a)

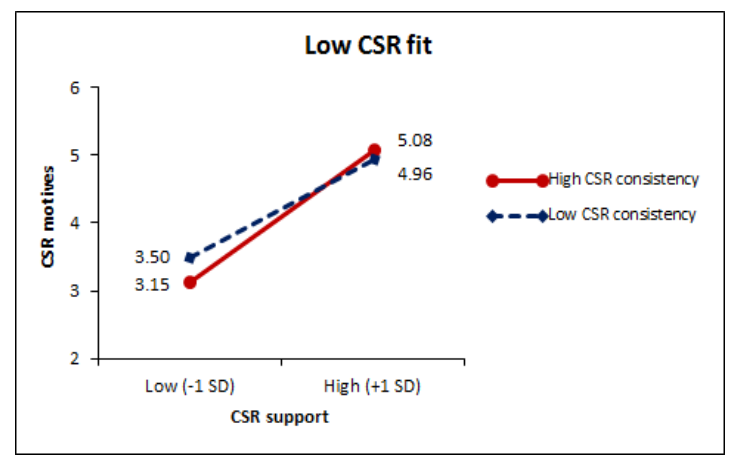

(b)

Figure 3. Interaction effects on CSR motives: (a) high-CSR fit condition; and, (b) low-CSR fit condition.

Our findings suggest that CSR support positively affects consumer perceptions about corporate motivation of CSR activities, regardless of the level of CSR fit and CSR consistency. In addition, 
the results show that when CSR support is low, consumers perceive the corporate motivation of CSR activities positively only on the condition of high-CSR fit and high-CSR consistency. Next, we run a mediation analysis using model 12 in PROCESS macro [73]. The mediation analysis was conducted with a bootstrapping analysis with 10,000 resamples [74]. As a result of analyzing the company evaluation by setting the independent variable as CSR fit, the moderate variables as CSR consistency and CSR support, and the mediate variable as CSR motives, there is a significant indirect effect (indirect effect $=-0.12,95 \%$ CI: $-0.3470 \sim-0.0051$ ). The results showed that the effects of CSR support, CSR fit, and CSR consistency on company evaluation are mediated by perceived CSR motives. The direct effect of the three-way interaction on company evaluation was found to become non-significant (direct effect $=-0.40,95 \%$ CI: $-0.9132 \sim 0.1075$ ) when perceived CSR motives were included in the model, suggesting full mediation. Thus, H3 was also supported.

\section{Discussion and Implications}

The purpose of this study is to examine the effect of CSR fit, CSR consistency, and CSR support on consumers' company evaluation. Even though many previous studies have examined diverse antecedents that affect CSR performance, this study investigated company evaluations from the perspective of consumers by utilizing CSR consistency, CSR support, as well as CSR fit to provide more generalizable and holistic results. The results of this study are summarized, as follows. First, consumer's support for CSR activities has a positive and significant influence on perceived CSR motives and company evaluations. This means that CSR support is an antecedent variable that influences consumer responses to CSR activities. This study contributed to the expansion of previous studies that only regarded CSR support as a moderating variable by verifying the independent role of CSR support $[18,75]$.

Second, we find that CSR support plays the role of a boundary condition on the effectiveness of CSR fit and CSR consistency. When CSR support is high, CSR fit and CSR consistency do not have a significant effect on company evaluation and perceived CSR motive. However, company evaluation and perceived CSR motive were significantly affected by CSR fit and consistency when CSR support is low. In the context of low CSR support, participants in the high-CSR fit and high-CSR consistency condition show more positive company evaluation and perceptions of CSR motives than those in the other conditions. That is, if either CSR fit or CSR consistency is low when CSR support is low, consumer thoughts about the corporate motivations of CSR activities are more elaborate, which lead to negative responses to the company.

The findings of this study provide several academic implications. First, previous research has examined the impact of CSR in the situation where a company engages in single CSR activity $[11,63]$. However, most companies undertake a variety of CSR activities; therefore, previous research is limited in deriving more generalizable results. Moreover, this study investigated the effect of the consistency between CSR activities in the case of companies implementing various CSR activities. Therefore, the results of this study extend previous research and provide more realistic implications.

Second, previous research that examined the effect of CSR activities on company evaluation has explained CSR fit as the foremost important variable [11,76]. However, this study confirmed that the CSR fit does not always lead to the positive results in consumers' company evaluation. In the case of companies implementing various CSR activities, consumers do not evaluate the company positively if the consistency between CSR activities is low, although the CSR fit is high. Moreover, the results of this study reveal that the degree of customer support for CSR activities is the utmost important variable. When consumer's support for CSR activities is high, consumers have positive company evaluation, regardless of the level of CSR fit and CSR consistency.

Third, we demonstrated the strong impact of CSR support on consumers' responses toward the company. Specifically, we found that CSR support acts as a boundary condition on the influence of CSR fit and CSR consistency. The influence of CSR fit and CSR consistency is attenuated when CSR support is high. We also confirmed the main effect of CSR support. This means that CSR support may 
act as an independent variable, unlike previous studies that considered CSR support as a moderating variable $[3,18]$. Thus, we extend the previous research on the role of CSR support, which mostly treat CSR support as a moderating variable that controls the role of other independent variables by finding out that CSR support is an independent variable that plays an important and direct role in the evaluation of CSR companies.

Finally, we revealed the hidden mechanism that explains the findings of this study by examining the mediating role of perceived CSR motives. The effects of CSR fit, CSR consistency, and CSR support on company evaluation were found to be mediated by consumers' perceived CSR motives.

This study also has several practical implications. First, it is not sufficient to consider only CSR fit when companies design successful CSR activities. In particular, companies engaging in various types of CSR activities should consider CSR consistency as well as CSR fit. Low consistency can convince consumers that companies are performing CSR activities for external factors, such as attracting customers or enhancing company reputation, rather than as a true social responsibility initiative. Therefore, marketers should incorporate CSR consistency when planning CSR activities. However, companies should keep in mind that high CSR consistency does not always have a positive impact on consumers' company evaluations. The results of this study showed that the influence of CSR consistency is significant only when CSR fit is high. In other words, CSR consistency is an important variable that positively affects consumers' evaluations, but high CSR fit must be preceded. In addition, companies sometimes fail to maintain CSR consistency due to government or social needs for specific CSR activities. In this case, companies should consider marketing communication strategies that can enhance consumers' perceived CSR consistency. For example, Hyundai Motors uses the names "Dream move" (supporting young people and vulnerable social groups), "Easy move" (enhancing Mobility for People with Disabilities), "Safe move" (establishing a safety-conscious culture), "Green move" (environmental protection), and "Happy move" (volunteer activities with employees and consumers) to perform different types of CSR activities. In this case, consistent CSR naming can be a good strategy for enhancing perceived CSR consistency. Meanwhile, if it is difficult for a company to maintain CSR consistency, it is desirable to focus on CSR support, because the results of this study revealed that the influence of CSR consistency is attenuated when CSR support is high.

Second, the results of this study show the strong impact of CSR support, including the main effect and interaction effect on perceived CSR motive and company evaluation. In particular, the influence of CSR fit and CSR consistency is attenuated when CSR support is high. Therefore, it is important for companies to understand the type of CSR activities that get the most support from their target customers, by understanding their characteristics. Companies must collect and analyze data on the desires and interests of their consumers and plan CSR activities based on the data. This can be an effective way to reach potential consumers, as well as induce positive attitudes from existing consumers.

Finally, if it is difficult for a company to find out consumer interests or design CSR activities in consumer support, and then CSR fit and CSR consistency must be fully reflected. The results of this study show that even if consumer support for CSR activities is low, consumers perceive the corporate motivation for CSR activities as positive, and evaluate the company favorably in the high CSR fit and high CSR consistency condition. If companies are implementing CSR activities with low CSR fit or low CSR consistency, consumers are more likely to perceive the corporate CSR activities as not being authentic or as hypocritical.

\section{Conclusions}

The findings of this study provide several academic and practical implications. However, this study has certain limitations and suggestions for future research. First, this study used only automobile manufacturers (Volvo) as experimental stimulants. Therefore, there is a limit to generalizing research results to other industries. Future research should employ other industries, such as service providers and distributors, as experimental stimuli. 
Second, the size of a company that is presented to participants may affect the results of this study. Volvo, the automobile manufacturer used in this study, is a relatively large company. According to Luo and Bhattacharya [4], the higher the quality of a product or the ability of a company to innovate, the more positive the company's performance in CSR activities. When the size of a company is large, consumer perceptions of quality or innovation capability may be higher. Therefore, future research will need to further investigate the variables related to corporate size.

Third, Becker-Olsen, Cudmore, and Hill [11] examined the relationship between corporate crises and CSR activity timing. The results of the study showed that consumers are more likely to elaborate their thoughts and have negative company evaluations and purchase intentions when a company performs CSR activities after a crisis, rather than before. Therefore, in future research, it is necessary to carry out the experiment while using variables that are related to the timing of CSR activity in the context of corporate crisis. We expect that even if CSR activities are implemented after the crisis, they will have relatively positive results if they are highly supported by consumers.

Author Contributions: Conceiving Research and Designing Research Framework, D.Y. and J.L.; Collecting and Analyzing Data, D.Y.; all authors wrote and reviewed the paper.

Funding: This research received no external funding.

Conflicts of Interest: The authors declare no conflicts of interest.

\section{Appendix A}

Box A1. Scenario example.

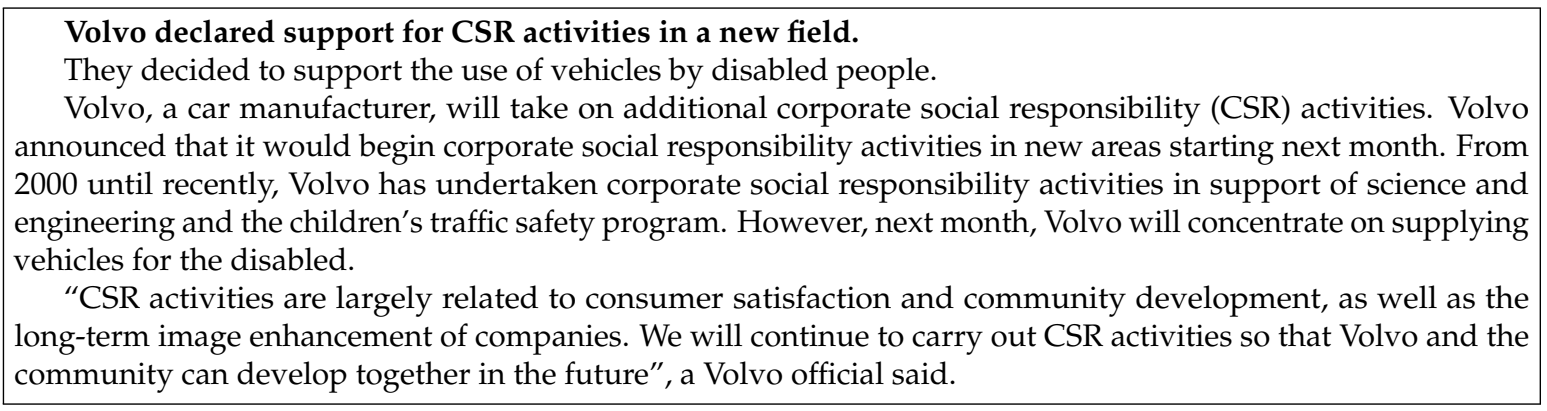

Table A1. CSR activities categorized by CSR fit and CSR consistency levels.

\begin{tabular}{|ll|}
\hline & Car Manufacturer (Volvo) \\
\hline High-CSR fit, high-CSR consistency & Low-CSR fit, high-CSR consistency \\
- Supporting science and engineering & - Sponsoring museums and art galleries \\
- Children's traffic safety program & - Protecting cultural properties \\
- Supplying vehicles for the disabled & - Popularizing culture and arts \\
\hline High-CSR fit, low-CSR consistency & Low-CSR fit, low-CSR consistency \\
- Energy welfare support program & - Eradicating pediatric cancer \\
- Supplying vehicles for the disabled & - Disaster relief \\
- Eco-friendly vehicle support program & - Popularizing culture and arts \\
\hline
\end{tabular}

\section{References}

1. Van Marrewijk, M. Concepts and definitions of csr and corporate sustainability: Between agency and communion. J. Bus. Ethics 2003, 44, 95-105. [CrossRef]

2. Tur-Porcar, A.; Roig-Tierno, N.; Llorca Mestre, A. Factors affecting entrepreneurship and business sustainability. Sustainability 2018, 10, 452. [CrossRef]

3. Du, S.; Bhattacharya, C.B.; Sen, S. Maximizing business returns to corporate social responsibility (csr): The role of csr communication. Int. J. Manag. Rev. 2010, 12, 8-19. [CrossRef] 
4. Luo, X.; Bhattacharya, C.B. Corporate social responsibility, customer satisfaction, and market value. J. Mark. 2006, 70, 1-18. [CrossRef]

5. Fombrun, C.; Shanley, M. What's in a name? Reputation building and corporate strategy. Acad. Manag. J. 1990, 33, 233-258.

6. Aupperle, K.E.; Carroll, A.B.; Hatfield, J.D. An empirical examination of the relationship between corporate social responsibility and profitability. Acad. Manag. J. 1985, 28, 446-463.

7. McGuire, J.B.; Sundgren, A.; Schneeweis, T. Corporate social responsibility and firm financial performance. Acad. Manag. J. 1988, 31, 854-872.

8. Nan, X.; Heo, K. Consumer responses to corporate social responsibility (csr) initiatives: Examining the role of brand-cause fit in cause-related marketing. J. Advert. 2007, 36, 63-74. [CrossRef]

9. Wagner, T.; Lutz, R.J.; Weitz, B.A. Corporate hypocrisy: Overcoming the threat of inconsistent corporate social responsibility perceptions. J. Mark. 2009, 73, 77-91. [CrossRef]

10. Yoon, Y.; Gürhan-Canli, Z.; Schwarz, N. The effect of corporate social responsibility (csr) activities on companies with bad reputations. J. Consum. Psychol. 2006, 16, 377-390. [CrossRef]

11. Becker-Olsen, K.L.; Cudmore, B.A.; Hill, R.P. The impact of perceived corporate social responsibility on consumer behavior. J. Bus. Res. 2006, 59, 46-53. [CrossRef]

12. Schwaiger, M.; Sarstedt, M.; Taylor, C.R. Art for the sake of the corporation: Audi, bmw group, daimlerchrysler, montblanc, siemens, and volkswagen help explore the effect of sponsorship on corporate reputations. J. Advert. Res. 2010, 50, 77-90. [CrossRef]

13. Hastie, R. Memory for behavioral information that confirms or contradicts a personality impression. In Person Memory (PLE: Memory): The Cognitive Basis of Social Perception; Psychology Press: New York, NY, USA, 1980; pp. 155-177.

14. Maheswaran, D.; Chaiken, S. Promoting systematic processing in low-motivation settings: Effect of incongruent information on processing and judgment. J. Pers. Soc. Psychol. 1991, 61, 13-25. [CrossRef] [PubMed]

15. McGuire, T.G. Financing Psychotherapy: Costs, Effects, and Public Policy; Ballinger Pub. Co.: Pensacola, FL, USA, 1981.

16. Sengupta, J.; Johar, G.V. Effects of inconsistent attribute information on the predictive value of product attitudes: Toward a resolution of opposing perspectives. J. Consum. Res. 2002, 29, 39-56. [CrossRef]

17. Srull, T.K.; Wyer, R.S. Person memory and judgment. Psychol. Rev. 1989, 96, 58-83. [CrossRef] [PubMed]

18. Sen, S.; Bhattacharya, C.B. Does doing good always lead to doing better? Consumer reactions to corporate social responsibility. J. Mark. Res. 2001, 38, 225-243. [CrossRef]

19. Pérez, A.; Rodríguez del Bosque, I. Customer personal features as determinants of the formation process of corporate social responsibility perceptions. Psychol. Mark. 2013, 30, 903-917. [CrossRef]

20. Mohr, L.A.; Webb, D.J.; Harris, K.E. Do consumers expect companies to be socially responsible? The impact of corporate social responsibility on buying behavior. J. Consum. Aff. 2001, 35, 45-72. [CrossRef]

21. Bolton, L.E.; Mattila, A.S. How does corporate social responsibility affect consumer response to service failure in buyer-seller relationships? J. Retail. 2015, 91, 140-153. [CrossRef]

22. Barone, M.J.; Miyazaki, A.D.; Taylor, K.A. The influence of cause-related marketing on consumer choice: Does one good turn deserve another? J. Acad. Mark. Sci. 2000, 28, 248-262. [CrossRef]

23. Brown, T.J.; Dacin, P.A. The company and the product: Corporate associations and consumer product responses. J. Mark. 1997, 61, 68-84. [CrossRef]

24. Du, S.; Bhattacharya, C.; Sen, S. Corporate social responsibility and competitive advantage: Overcoming the trust barrier. Manag. Sci. 2011, 57, 1528-1545. [CrossRef]

25. Du, S.; Bhattacharya, C.B.; Sen, S. Reaping relational rewards from corporate social responsibility: The role of competitive positioning. Int. J. Res. Mark. 2007, 24, 224-241. [CrossRef]

26. Ellen, P.S.; Webb, D.J.; Mohr, L.A. Building corporate associations: Consumer attributions for corporate socially responsible programs. J. Acad. Mark. Sci. 2006, 34, 147-157. [CrossRef]

27. Luo, X.; Bhattacharya, C.B. The debate over doing good: Corporate social performance, strategic marketing levers, and firm-idiosyncratic risk. J. Mark. 2009, 73, 198-213. [CrossRef]

28. Stanwick, P.A.; Stanwick, S.D. The relationship between corporate social performance, and organizational size, financial performance, and environmental performance: An empirical examination. J. Bus. Ethics 1998, 17, 195-204. [CrossRef] 
29. Manes-Rossi, F.; Tiron-Tudor, A.; Nicolò, G.; Zanellato, G. Ensuring more sustainable reporting in europe using non-financial disclosure-De facto and de jure evidence. Sustainability 2018, 10, 1162. [CrossRef]

30. Venturelli, A.; Caputo, F.; Cosma, S.; Leopizzi, R.; Pizzi, S. Directive 2014/95/eu: Are italian companies already compliant? Sustainability 2017, 9, 1385. [CrossRef]

31. Drazin, R.; Van de Ven, A.H. Alternative forms of fit in contingency theory. Adm. Sci. Q. 1985, 30, 514-539. [CrossRef]

32. Varadarajan, P.R.; Menon, A. Cause-related marketing: A coalignment of marketing strategy and corporate philanthropy. J. Mark. 1988, 58-74. [CrossRef]

33. Forehand, M.R.; Grier, S. When is honesty the best policy? The effect of stated company intent on consumer skepticism. J.Consum. Psychol. 2003, 13, 349-356.

34. Meyers-Levy, J.; Louie, T.A.; Curren, M.T. How does the congruity of brand names affect evaluations of brand name extensions? J. Appl. Psychol. 1994, 79, 46. [CrossRef]

35. Meyers-Levy, J.; Tybout, A.M. Schema congruity as a basis for product evaluation. J. Consum. Res. 1989, 16, 39-54. [CrossRef]

36. Menon, S.; Kahn, B.E. Corporate sponsorships of philanthropic activities: When do they impact perception of sponsor brand? J. Consum. Psychol. 2003, 13, 316-327. [CrossRef]

37. Simmons, C.J.; Becker-Olsen, K.L. Achieving marketing objectives through social sponsorships. J. Mark. 2006, 70, 154-169. [CrossRef]

38. Speed, R.; Thompson, P. Determinants of sports sponsorship response. J. Acad. Mark. Sci. 2000, 28, $226-238$. [CrossRef]

39. Feltham, T.S.; Arnold, S.J. Program involvement and ad/program consistency as moderators of program context effects. J. Consum. Psychol. 1994, 3, 51-77. [CrossRef]

40. Park, C.W.; Zaltman, G. Marketing Management; Harcourt School: Harcourt, NB, Canada, 1987.

41. Swait, J.; Erdem, T. The effects of temporal consistency of sales promotions and availability on consumer choice behavior. J. Mark. Res. 2002, 39, 304-320. [CrossRef]

42. Tang, Z.; Hull, C.E.; Rothenberg, S. How corporate social responsibility engagement strategy moderates the csr-financial performance relationship. J. Manag. Stud. 2012, 49, 1274-1303. [CrossRef]

43. Bargh, J.A.; Chaiken, S.; Govender, R.; Pratto, F. The generality of the automatic attitude activation effect. J. Pers. Soc. Psychol. 1992, 62, 893-912. [CrossRef] [PubMed]

44. Thompson, M.M.; Zanna, M.P.; Griffin, D.W. Let's Not Be Indifferent about (Attitudinal) Ambivalence; Lawrence Erlbaum Associates: Mahwah, NJ, USA, 1995; pp. 361-386.

45. Gentner, D.; Nielsen, J. The anti-mac interface. Commun. ACM 1996, 39, 70-82. [CrossRef]

46. Gürhan-Canli, Z.; Batra, R. When corporate image affects product evaluations: The moderating role of perceived risk. J. Mark. Res. 2004, 41, 197-205. [CrossRef]

47. Drumwright, M.E. Company advertising with a social dimension: The role of noneconomic criteria. J. Mark. 1996, 60, 71-87. [CrossRef]

48. Haley, E. Exploring the construct of organization as source: Consumers' understandings of organizational sponsorship of advocacy advertising. J. Advert. 1996, 25, 19-35. [CrossRef]

49. Creyer, E.H. The influence of firm behavior on purchase intention: Do consumers really care about business ethics? J. Consum. Mark. 1997, 14, 421-432. [CrossRef]

50. Stryker, S.; Burke, P.J. The past, present, and future of an identity theory. Soc. Psychol. Q. 2000, 63, $284-297$. [CrossRef]

51. Laverie, D.A.; Arnett, D.B. Factors affecting fan attendance: The influence of identity salience and satisfaction. J. Leis. Res. 2000, 32, 225-246. [CrossRef]

52. McCall, G.J.; Simmons, J.L. Identities and Interactions: An Examination of Human Associations in Everyday Life; The Free Press: New York, NY, USA, 1978.

53. Stryker, S. Identity salience and role performance: The relevance of symbolic interaction theory for family research. J. Marriage Fam. 1968, 30, 558-564. [CrossRef]

54. Callero, P.L. Role-identity salience. Soc. Psychol. Q. 1985, 48, 203-215. [CrossRef]

55. Arnett, D.B.; German, S.D.; Hunt, S.D. The identity salience model of relationship marketing success: The case of nonprofit marketing. J. Mark. 2003, 67, 89-105. [CrossRef]

56. Bae, S.M.; Masud, M.A.K.; Kim, J.D. A cross-country investigation of corporate governance and corporate sustainability disclosure: A signaling theory perspective. Sustainability 2018, 10, 2611. [CrossRef] 
57. Tsao, H.Y.; Berthon, P.; Pitt, L.F.; Parent, M. Brand signal quality of products in an asymmetric online information environment: An experimental study. J. Consum. Behav. 2011, 10, 169-178. [CrossRef]

58. Dawar, N.; Parker, P. Marketing universals: Consumers' use of brand name, price, physical appearance, and retailer reputation as signals of product quality. J. Mark. 1994, 58, 81-95. [CrossRef]

59. Maity, M.; Dass, M.; Malhotra, N.K. The antecedents and moderators of offline information search: A meta-analysis. J. Retail. 2014, 90, 233-254. [CrossRef]

60. Yamamoto, T.; Li, C.; Morikawa, T. An empirical analysis of the factors raising the interest in new shopping destinations. J. Retail.Consum. Serv. 2014, 21, 950-957. [CrossRef]

61. Sinha, I.; DeSarbo, W.S. An integrated approach toward the spatial modeling of perceived customer value. J. Mark. Res. 1998, 35, 236-249. [CrossRef]

62. Xia, L.; Monroe, K.B.; Cox, J.L. The price is unfair! A conceptual framework of price fairness perceptions. J. Mark. 2004, 68, 1-15. [CrossRef]

63. Karaosmanoglu, E.; Altinigne, N.; Isiksal, D.G. Csr motivation and customer extra-role behavior: Moderation of ethical corporate identity. J. Bus. Res. 2016, 69, 4161-4167. [CrossRef]

64. Alhouti, S.; Johnson, C.M.; Holloway, B.B. Corporate social responsibility authenticity: Investigating its antecedents and outcomes. J. Bus. Res. 2016, 69, 1242-1249. [CrossRef]

65. Park, J.; Lee, H.; Kim, C. Corporate social responsibilities, consumer trust and corporate reputation: South Korean consumers' perspectives. J. Bus. Res. 2014, 67, 295-302. [CrossRef]

66. He, Y.; Lai, K.K. The effect of corporate social responsibility on brand loyalty: The mediating role of brand image. Total Qual. Manag. 2014, 25, 249-263. [CrossRef]

67. Grau, S.L.; Folse, J.A.G. Cause-related marketing (crm): The influence of donation proximity and message-framing cues on the less-involved consumer. J. Advert. 2007, 36, 19-33. [CrossRef]

68. Buhrmester, M.; Kwang, T.; Gosling, S.D. Amazon's mechanical turk: A new source of inexpensive, yet high-quality, data? Perspect. Psychol. Sci. 2011, 6, 3-5. [CrossRef] [PubMed]

69. Paolacci, G.; Chandler, J.; Ipeirotis, P.G. Running experiments on amazon mechanical turk. Judgm. Decis. Mak. 2010, 5, 411-419.

70. Siano, A.; Vollero, A.; Conte, F.; Amabile, S. "More than words": Expanding the taxonomy of greenwashing after the volkswagen scandal. J. Bus. Res. 2017, 71, 27-37. [CrossRef]

71. Stamoulakis, D.; Bridwell, L. Bmw's Approach to Global Warming and Environmental Management: Corporate Social Responsibility or Greenwashing? Competition Forum: New York, NY, USA; American Society for Competitiveness: Indiana, PA, USA, 2009; p. 98.

72. Aiken, L.S.; West, S.G.; Reno, R.R. Multiple Regression: Testing and Interpreting Interactions; Sage: New Delhi, India, 1991.

73. Preacher, K.J.; Hayes, A.F. Asymptotic and resampling strategies for assessing and comparing indirect effects in multiple mediator models. Behav. Res. Methods 2008, 40, 879-891. [CrossRef] [PubMed]

74. Zhao, X.; Lynch, J.G., Jr.; Chen, Q. Reconsidering baron and kenny: Myths and truths about mediation analysis. J. Consum. Res. 2010, 37, 197-206. [CrossRef]

75. Bhattacharya, C.B.; Sen, S. Doing better at doing good: When, why, and how consumers respond to corporate social initiatives. Calif. Manag. Rev. 2004, 47, 9-24. [CrossRef]

76. Zasuwa, G. The role of company-cause fit and company involvement in consumer responses to csr initiatives: A meta-analytic review. Sustainability 2017, 9, 1016. [CrossRef]

(C) 2018 by the authors. Licensee MDPI, Basel, Switzerland. This article is an open access article distributed under the terms and conditions of the Creative Commons Attribution (CC BY) license (http://creativecommons.org/licenses/by/4.0/). 